\title{
Director Training and Financial Disclosure: Asian Insights
}

\author{
Qaiser Rafique Yasser ${ }^{1}$, Abdullah Al Mamun², Marcus Rodrigs²
}

\begin{abstract}
We provide evidence regarding the relationship between director training programs and improved financial reporting. Director Training Programs (DTP) help directors better understand the specific context in which a firm operates, including its operations and environment; awareness of business norms and values; standards of probity and accountability; and their fiduciary duties as an agent of investors. This study explores a recent requirement for director training and its effect on the quality of financial reporting for publicly listed companies in three eastern countries. This study examines the relationship between DTP and the quality of financial reporting of Australian, Malaysian and Pakistani publicly listed companies by using a sample of data from 2011 to 2013. We determined that Australian companies that incur additional DTP expenditures and have a flexible training schedule (Online DTP)improve their financial reporting quality and that a wellestablished DTP positively affects financial reporting quality in Malaysia. In addition, the results indicate that firm size negatively affects financial reporting quality in the Asia Pacific and older companies (firm age) suffer from low-quality financial reporting.
\end{abstract}

KEY WORDS: $\quad$ Director training, financial reporting quality

JEL Classification: $\quad$ G34

${ }^{1}$ University Malaysia Sarawak, Malaysia; ${ }^{2}$ University of Newcastle - Newcastle Business School, Australia

\section{Introduction}

Recent accounting scandals in the international financial community have raised many concerns regarding the quality of periodical financial disclosures (Agrawal \& Chadha, 2005; Bowen, Call, \& Rajgopal, 2010). Several prominent companies have suffered from accounting fraud and incompetent management, including Enron, WorldCom, HIH Insurance, and Parmalat,

-

Correspondence concerning this article should be addressed to: Qaiser Rafique Yasser, University Malaysia Sarawak, Malaysia - FEB Kota Samarahan, Kuching 94300, Malaysia E-mail: qaiser_rafique1@hotmail.com which has weakened principals' (investors) confidence in Agents (directors)and the eminence of financial reports (Beekes \& Brown, 2006; Brown \& Caylor, 2006; Firth, Fung, \& Rui, 2007; Karamanou \& Vafeas, 2005; Petra, 2007). Now, more than ever before, directors must understand their fiduciary, legal and ethical responsibilities because the bar has been raised. Investors' confidence in corporations has reached an alltime low, and the role of directors has become even more challenging and demanding (Bowen et al., 2010; Easley \& O’Hara, 2004; Grossman \& Haskisson, 1998; Peasnell, Pope, \& Young, 2005;). According to Sloan (2001), financial information is the first source of independent and factual communication regarding the 
performance of a company and its directors, which makes financial reporting a primary indicator of management's control and proficiency.

Doh (2003) suggests that individuals can be taught how to engage in effective board leadership and systematic training programs affect organizations' leadership strategies (Barling, Weber, \& Kelloway, 1996; Dvir, Eden, Avolio, \& Shamir, 2002). Parry and Sinha (2005) investigate the effects of training and report a significant increase in leadership strategies and a significant effect on performance through the enhancement of transformational strategies (Dvir et al., 2002). In addition, leadership training significantly affects self-reported employee variables such as employee commitment (Barling et al., 1996) follower development (Dvir et al., 2002), satisfaction with leadership (Hassan, Fuwad, \& Rauf, 2010) extra follower effort (Parry \& Sinha, 2005) and certain objective performance measures (Barling et al., 1996). However, the impact of director training programs on the financial reporting quality is not well understood. Recently, the association between leadership characteristics and financial reporting quality has been discussed in developed countries. Emphasis was placed on specific governance mechanisms including insider domination of shareholding (Yeo, Tan, Ho, \& Chen, 2002;), board independence (Beekes, Pope, \& Young, 2004; Bradbury, Mak, \& Tan, 2006; Petra, 2007), director shareholding (Sánchez-Ballesta \& García-Meca, 2007) and the reputation of the auditing firm (Agrawal \& Chadha, 2005). Recent studies have analyzed board attributes and financial reporting quality in rapidly growing emerging economies that have distinctive features of corporate control, capital allocation and regulations (Bradbury et al., 2006; Dimitropoulos \& Asteriou, 2010; Firth et al., 2007).

Countries around the world are characterized by their corporate governance systems and scholars debate the efficiency, superiority and effectiveness of these systems. We use a dataset that includes large Australian, Malaysian and Pakistani firms; these three Anglo-Saxon countries have common characteristics in terms of their basic governance systems (La Porta, Lopez-de-Silanes, Shleifer, \& Vishny, 1998). Prowse (1992) suggests that judgments are inherently subjective because of sparse evidence regarding the relative performance of different corporate governance systems. Existing studies have generally examined the effects of corporate governance characteristics of firms that operate in only one country on earnings management (Armstrong, Barth, Jagolinzer, \& Riedl, 2010; Larcker, Richardson, \& Tuna 2007; Yasser \& Mamun, 2015). In this study, we seek to fill this gap in the extant literature.

This study seeks to analyze the following question: Do the director training programs of publically listed companies affect the quality of their financial reporting? To address this question, we built a dataset by collecting data from the Australian Stock Exchange, the Kuala Lumpur Stock Exchange and the Pakistan Stock Exchange. We empirically analyzed the effect of director training programs on earnings management by examining a sample of matched industrial companies that are listed on the stock exchanges of the sample countries. Data were collected from annual reports and when necessary, these data were complemented and crosschecked with the corporate websites of the sample companies. First, we provide a review of prior empirical studies, which is followed by our hypotheses, the method, the study results, a discussion, and the conclusion.

\section{Review of Prior Studies and Hypotheses}

Mole (2000) distinguishes between training, education and development and proposes that training focuses on the present job, education focuses on a future job, and development focuses on the organization. Although some of the more traditional modes of provision, particularly for formal management programs, seek to enhance skills and knowledge and adopt a training approach, the current trend focuses more on education and development as indicated by the following statement: "Development programs prepare individuals to move in the new directions that organizational change may require" (Mole, 2000, p. 22).

Professional development is an important topic that is related to the characteristics of top management because it is related to distinct patterns of decision makers' cognitive processes, attention and final decisions (Wiersema \& Bantel, 1992). In addition, Hambrick and Fukutomi (1991) suggest that managers are generally engaged in complicated, ambiguous and information overloaded situations. This implies that managers operate within a finite model or paradigm 
despite making use of all of the available information. Long-tenured managers are fixated on this paradigm, which makes it difficult for them to pay a great deal of attention to outside sources of information.

Hambrick and Mason (1984) argue that the demographic characteristics of top management including experience, age, gender and tenure affect their values and cognitive bases, which subsequently affect their decision-making and choices, particularly in complex situations and ultimately result in different organizational outcomes. Bertrand and Schoar (2003) developed an innovative design to determine that managers' personal characteristics influence their investment or financial decisions after controlling for firm and time fixed effects. This methodology has been applied by other studies, including Bamber, Jiang, and Wang (2010), which demonstrated that executives' disclosure styles are related to their personal backgrounds. These scholars argue that older executives use a conservative disclosure style and finance and accounting managers use a more precise disclosure style.

Although numerous studies have examined whether financial reporting quality is influenced by various governance mechanisms, generally, the empirical evidence has been mixed (Armstrong et al., 2010). In addition, prior studies that examine managerial compensation and its impact on financial reporting have failed to produce consistent results. Furthermore, certain studies have determined that a negative relationship exists between directors' equity incentives and the quality of financial reporting (Bergstresser \& Philippon, 2006; Cheng \& Warfield, 2005; Efendi, Srivastava, \& Swanson, 2007); however, certain studies were unable to confirm that a relationship exists between directors' equity incentives and the quality of financial reporting (Baber, Liang, \& Zhu, 2012; Erickson, Hanlon, \& Maydew, 2006) and other studies reported that a positive relationship exists (Armstrong et al., 2010).

Studies that have examined the effects of various features of boards of directors on financial reporting have determined that more independent boards are associated with higher quality reporting (Efendi et al., 2007; Klein, 2002); however, other studies provided little evidence that board independence has a significant impact on financial reporting quality (Agarawal \& Chadha, 2005; Kim \& Qi, 2010; Larcker et al., 2007). Although numerous factors may contribute to the mixed results that are reported by extant literature, the joint endogeneity of corporate governance and financial reporting represents perhaps the greatest challenge (Armstrong et al., 2010). In addition, a companies' selection of a particular governance mechanism is endogenously determined by numerous factors, including firm fundamental characteristics, information environments, other governance mechanisms, and managerial attributes.

Most prior studies regarding the quality of financial reporting have focused on firm characteristics and other environmental factors (Dechow \& Dichev, 2002; Dechow, Ge, \& Schrand, 2010). However, agency theory suggests that decision makers are affected by contractual incentives and an organization's monitoring mechanisms and growth (Decker \& Calo, 2007; Hermalin \& Weisbach, 1998;). Conversely, the upper echelons theory suggests that directors' demographic characteristics and skills are associated with their unique cognitive styles and values and affect the managerial decision-making processes (Hambrick \& Mason, 1984; Hermalin \& Weisbach, 2003). Bertrand and Schoar (2003) documented that executive's demographic characteristics affect their decision-making capacity and accounting policies. In addition, Bamber et al. (2010) and Dyreng, Hanlon, and Maydew (2010) suggest that executive-specific fixed effects reflect systematic differences in executives' disclosure styles and tax avoidance strategies.

Prior studies propose that executive training can be used to develop needed competencies and help companies' strategic personnel to succeed in their specific organizational contexts (Burke \& Hutchins, 2007). The effectiveness of director training has been studied from three different perspectives: the effects of training on attitudinal outcomes of trainees (Howell \& Frost, 1989), the effects of training on subordinates' task performance (Kirkpatrick \& Locke, 1996) and the impact of training on financial outcomes (Barling et al., 1996).

Studies regarding the impact of training on skill development have demonstrated that this effect is stronger for technical training than more complex types of managerial training programs and the effects of training are more significant for skills that can be segmented into step-by-step routines than for soft skills (Hunt \& Baruch, 2003). Training could amplify the benefits of learning routines if regular reviews of performance 
trends are conducted through performance analysis, problem solving, and oral communication skills. In addition, training may better leverage discretion by increasing management's capacity to diagnose and redesign processes or by facilitating the appropriate use of targets and incentives to motivate employees (Kim \& Qi, 2010).

Executive training conveys basic information regarding reform and its requirements; simply knowing more about a reform may encourage employees to implement the reform. This type of declarative knowledge (information about something) is generally perceived as inferior to procedural or tacit knowledge (information about how or which, when, and why) (Aguinis \& Kraiger, 2009). However, providing information regarding important reform concepts, changes to central processes and routines, and expectations and rewards appear to be related to fundamental lower-order conditions for behavioral change. Prior studies have examined the effects of various features of boards of directors on financial reporting quality, but the results are mixed. For example, certain studies determined that directors' financial expertise is associated with higher quality reporting (e.g., Klein, 2002; Efendi et al., 2007), but other studies were unable to confirm that directors' financial expertise had a significant impact on the quality of financial reporting (e.g., Agarawal and Chadha, 2005; Larcker et al., 2007). Therefore, we propose the following hypothesis:

Hypothesis: Director training programs have a positive impact on financial reporting quality.

\section{Regulatory Framework for Director Training}

A code of corporate governance is the primary regulatory framework for a company according to statutes that have been enacted to improve the governance practices of firms that operate in each of the sample countries. Guidelines for developing code of corporate governance for promoting Director Training Programs (DTP) for each of the sample countries are as follows:

- Malaysia

The Malaysian revised code of corporate governance (2012) recommends that the board of directors ensures that its members have access to appro- priate continuing education programs. In addition, the code of corporate governance should include the following:

"In a dynamic and complex business environment, it is imperative that directors devote sufficient time to update their knowledge and strengthen their skills through appropriate continuing education programs and life-long learning. This will enable directors to sustain their active participation in board deliberations. Director(s) should notify the chairman of the board of the planned and estimated time that will be spent on the training and development of new directorship appointments before accepting any new directorship. The nominating committee is responsible for reviewing the director's training program" (Section 4.2).

\section{- Australia}

The Codes of corporate governance that were issued in 2014 focus on DTP and require that each listed entity have a program for inducting new directors and providing appropriate professional development opportunities for directors to develop and maintain the skills and knowledge that directors need to effectively perform their roles.

"The board or nomination committee of a listed entity should regularly review whether the directors as a group have the skills, knowledge and familiarity with the entity and its operating environment required to effectively fulfill their role on the board and on board committees and, where any gaps are identified, consider what training or development could be undertaken to fill those gaps. Where necessary, the entity should provide resources to help develop and maintain its directors' skills and knowledge. This includes, in the case of a director who does not have specialist accounting skills or knowledge, ensuring that he or she has a sufficient understanding of accounting matters to fulfill his or her responsibilities in relation to the entity's financial statements. It also ensures that all directors receive ongoing briefings on developments in accounting standards" (Section 2.6).

\section{- Pakistan}

The revised Codes of corporate governance that were issued in 2012 specify the requirements for 
Table 1. Selection of Variables

\begin{tabular}{llcc}
\hline Country & Index & Companies & Percentage \\
\hline Australia & Australia Stock Exchange & 90 & $33.33 \%$ \\
Malaysia & Kuala Lumpur Stock Exchange & 90 & $33.33 \%$ \\
Pakistan & Pakistan Stock Exchange & 90 & $33.33 \%$ \\
Total Sample Companies (Three Years: 2011 to 2013) & 270 & $100.0 \%$ \\
\hline
\end{tabular}

director training programs of locally listed companies by stating the following:

\begin{abstract}
"All listed companies shall make appropriate arrangements to provide orientation courses for their directors to acquaint them with this code, applicable laws, their duties and responsibilities to enable them to effectively manage the affairs of the listed companies for and on behalf of shareholders. It shall be mandatory for all the directors of listed companies to be certified by any directors' training program offered by institutionslocal or foreign-that meets the criteria as specified by the SECP. From June 30, 2012 to June 30, 2016, every year, a minimum of one director on the board shall obtain the said certification under this program each year and thereafter, all directors shall obtain it. Furthermore, individuals with a minimum of 14 years of education and 15 years of experience on the board of a listed company local and/or foreign shall be exempted from the directors' training program" (Section xi).
\end{abstract}

\section{Research Methodology}

The dataset includes a large sample of firms that operate in multiple sectors (manufacturing, services, agriculture, and construction). We describe our sample selection procedure in Table 1. The primary constraint on our sample size is the availability of data from 2011 to 2013 for companies that operate in Australia, Malaysia and Pakistan. The top indexed companies used in this study were obtained from the Australian Stock Exchange (AXS), the Kuala Lumpur Stock Exchange (KLSE) and the Pakistan Stock Exchange (PSE); 33.3\% of the firms in the sample were obtained from each stock exchange.

\section{Multivariate Regression Models}

In the multivariate analysis, we used the absolute value of the residue of the regression models to mea- sure the quality of the accruals. Dechow and Dichev (2002) and Francis, LaFond, Olsson, and Schipper (2005) used the standard deviation of errors in the estimation of accruals to measure the quality of the accruals; however, we use the absolute value of this residue. Multivariate regression models were used to analyze the relationship between DTP and financial reporting quality as follows:

\section{Financial Reporting Quality =}

$=A R+P A a c c r+T C a c c r+A G G R E$

Financial Reporting Quality $=$

$=\alpha+\beta_{1} \mathrm{DTP}+\beta_{2}$ Control $+\epsilon$

\section{Dependent, Explanatory and Control Variables}

The variables that are used in our equations are described in Table 2 .

\section{Independent Variables}

DTP starts (DTPY) refer to the number of year(s), beginning in 2011, that sample companies offered director training programs. However, the variable 'DTP expense' (DTPX) represents the amount of money (in USD millions) that the company spent for the development of the board of directors during the sample year. Because members of the board members generally have busy schedules, most companies use online DTP. The variable 'Online DTP' (Online) represents the status of DTP delivery and is a dummy variable that is set as " 1 " as if the DTP is offline/physical and "0" otherwise. Specific AC is a variable that indicates the scope of DTP regarding the needs of audit committee members. For this dummy variable, " 1 " used if the specific audit committee needs DTP and "0" otherwise. 
Table 2. Definition of Variables

\begin{tabular}{|c|c|c|c|}
\hline Sr. \# & Variable & & Description \\
\hline \multicolumn{4}{|c|}{ Independent Variable } \\
\hline (A) & DTPY & DTP Start (Year) & Number of year(s) since DTP was launched for the first time. \\
\hline (B) & DTPX & DTP Expenses & The amount of DTP expenditures. \\
\hline (C) & SPAC & Specific Audit Committee Training & $\begin{array}{l}\text { Dummy variable and is ' } 1 \text { ' if there is a specific DTP for Audit } \\
\text { Committee members and ' } 0 \text { ' otherwise. }\end{array}$ \\
\hline (D) & Online & Training Status & Dummy variable and is ' 1 ' if the DTP is offline and' 0 ' otherwise. \\
\hline \multicolumn{4}{|c|}{ Dependent Variables } \\
\hline (E) & PAaccr & $\begin{array}{l}\text { Performance Adjusted } \\
\text { Discretionary Accrual }\end{array}$ & $\begin{array}{l}\text { Total accruals are measured as the change in non-cash current } \\
\text { assets minus the change in current non-interest bearing liabilities, } \\
\text { minus depreciation and amortization expense, scaled by lagged } \\
\text { total assets. }\end{array}$ \\
\hline$(\mathrm{F})$ & $A R$ & Discretionary Revenue & The annual change in revenues and scaled by lagged total assets. \\
\hline (G) & TCaccr & Total Current Accruals & $\begin{array}{l}\text { Total current accruals are measured as the change in non-cash } \\
\text { current assets minus the change in current non-interest bearing } \\
\text { liabilities, scaled by lagged total assets. }\end{array}$ \\
\hline$(\mathrm{H})$ & Aggre. & Aggregate Accruals & An average of PAaccr, AR and TCaccr. \\
\hline \multicolumn{4}{|c|}{ Control Variables } \\
\hline (l) & FSIZE & Firm Size & The log of total assets \\
\hline$(J)$ & $\mathrm{FL}$ & Financial Leverage & Total Debt/Total Equity \\
\hline$(K)$ & $\mathrm{Bl}$ & Board Independence & Percentage of non-executive director in board \\
\hline$(\mathrm{L})$ & FAGE & Firm Age & Number of years from the incorporation. \\
\hline
\end{tabular}

\section{Control Variables}

Motivated by prior empirical studies, we include firm size, board independence, financial leverage and firm age as control variables (Owolabi, Obiakor, \& Okwu, 2011; Raheman \& Nasr, 2007). To control for firm size, we included a variable for the natural logarithm of total assets (FSIZE). Firm age was calculated as the natural logarithm of the number of years since the incorporation of the firm, which helped to control for the organization's maturity (Arthurs, Hoskisson, Busentiz, \& Johnson 2008; Matta \& Beamish, 2008). The logarithmic form of analysis was applied to reduce heteroscedasticity (Finkelstein \& D'Aveni, 1994). Hutchinson and Gul (2004) argued that a firm's leverage may lead to increased external control because creditors would monitor its capital structure more intensively to protect their interests. In alignment with Chen and Jaggi (2000), the debt-to-equity ratio (FL) was used to measure firm leverage.

\section{Dependent Variables (Proxies for Financial Reporting Quality)}

A solitary universally recognized measure for financial reporting quality has not been developed (Dechow et al. 2010). This study employs three measures that have been used in prior studies and an aggregate measure is included for the following reasons. First, this study focuses on financial reporting quality, which is multi-dimensional. Therefore, a single proxy may not include all of the facets of financial reporting quality. Second, the use of multiple proxies increases the adequacy of our results. Third, using alternative measures mitigates the possibility that results using one particular proxy capture a factor other than financial reporting quality.

The first measure is performance-adjusted discretionary accruals as proposed by Ashbaugh, LaFond, and Mayhew (2003), Kothari, 
Leone, \& Wasley (2005) and Chen, Harford, and Li (2007).

$$
\begin{aligned}
& \text { PAaccr }_{i, t}=\alpha_{0}+\alpha_{1}\left(\frac{1}{\text { Assets }_{i, t-1}}\right)+\alpha_{2} \Delta \operatorname{Rev}_{i, t}+ \\
& +\alpha_{3} P P E_{i, t}+\alpha_{4} \operatorname{ROA}_{i, t}+\epsilon_{i, t}
\end{aligned}
$$

where, PAaccr $_{i, t}$ total accruals is measured as the change in non-cash current assets minus the change in current non-interest bearing liabilities, minus depreciation and amortization expenses for firm $i$ at year $t$, scaled by lagged total assets $\left(\right.$ Assets $\left._{i, t}\right) ; \Delta \operatorname{Rev}_{i, t}$ represents the annual change in revenues scaled by lagged total assets; $P P E_{i, t}$ represents property, plant, and equipment for firm $i$ at year $t$, scaled by lagged total assets; and $R O A_{i, t}$ represents return on assets for firm $i$ at year $t$. The residuals from the regression model are discretionary accruals. In our tests, we use the absolute values of discretionary accruals as a proxy for financial reporting quality. We multiply the absolute values of discretionary accruals by -1. Therefore, higher values of PAaccr represent higher financial reporting quality.

To calculate the second proxy, we align with Chen et al. (2007), McNichols and Stubben (2008) and use the following regression:

$$
\Delta A R_{i, t}=\alpha_{0}+\alpha_{1} \Delta \operatorname{Rev}_{i, t}+\epsilon_{i, t}
$$

where, $\Delta A R_{i, t}$ represents the annual change in accounts receivable and $\Delta R e v_{i, t}$ represents the annual change in revenues, scaled by lagged total assets. Discretionary revenues are the residuals from Equation (2) that are estimated separately for each industry-country group. Our third proxy is based on the cross-sectional Dechow and Dichev (2002) and Tucker and Zarowin (2006) model, as modified by McNichols (2002), Francis et al. (2005) and Chen et al. (2007).

$$
\begin{aligned}
& \text { TCaccr }_{i, t}=\alpha_{0}+\alpha_{1} O C F_{i, t-1}+\alpha_{2} O C F_{i, t}+\alpha_{3} O C F_{i, t+1}+ \\
& +\alpha_{4} \Delta \operatorname{Rev}_{i, t}+\alpha_{5} P P E_{i, t}+\epsilon_{i, t}
\end{aligned}
$$

where, TCaccr represents total current accruals, which are measured as the change in non-cash current assets minus the change in current noninterest bearing liabilities, scaled by lagged total assets; OCF represents cash flow from operations, which is measured as the sum of net income, depreciation and amortization, and changes in current liabilities, minus changes in current assets, scaled by lagged total assets; $\Delta R e v_{i, t}$ represents the annual change in revenues scaled by lagged total assets; and $P P E_{i, t}$ represents property, plant, and equipment, scaled by lagged total assets.

The residuals from Equation (3) represent the estimation errors in the current accruals that are not associated with operating cash flows and cannot be explained by changes in revenue and levels of property, plant and equipment. Because of the short longitudinal time frame that is used in our study, we align with Srinidhi and Gul (2007) and Chen et al. (2007) and use the absolute value of this residual as a proxy for financial reporting quality. Therefore, higher values of TCaccr represent higher financial reporting quality. To reduce the measurement errors of the financial reporting quality mechanism and to present evidence based on general financial reporting metrics, we aggregate these proxies into one score. In alignment with Biddle, Hilary, and Verdi (2009), we normalize all proxies and then calculate the average of the three measures as our summary financial reporting quality statistic (AGGRE).

\section{Empirical Results}

\section{Descriptive Statistics}

Table 3 provides the descriptive statistics for the variables that are used in our primary tests. The number of observations varies with data availability and selection for each dependent variable because we utilize all available observations for each measure of financial reporting quality.

The results indicate that the mean value of 'DTP Start' is lowest in Pakistan at 6 years and is 12 years in Malaysia and 24 years in Australia. However, DTP expenditures are highest in Malaysia with a mean value of 29.61 million and are 21.23 million in Pakistan and 29 million in Australia, with a minimum expense of 0.20, 2.8 and 10 million in Pakistan, Malaysia and Australia, respectively. 
Table 3. Descriptive Statistics

\begin{tabular}{lcccccccccccc}
\hline & \multicolumn{4}{c}{ Australia } & \multicolumn{4}{c}{ Malaysia } & \multicolumn{4}{c}{ Pakistan } \\
\hline DTP Start & Min. & Max. & Mean & SD & Min. & Max. & Mean & SD & Min. & Max. & Mean & SD \\
DTP Expense & 9.0 & 36.0 & 23.85 & 8.15 & 3.0 & 24.0 & 12.23 & 4.13 & 1.0 & 15.0 & 5.87 & 3.71 \\
Specific AC & 10.0 & 43.0 & 28.87 & 6.81 & 2.8 & 58.0 & 29.61 & 12.11 & 0.20 & 170.8 & 21.23 & 81.9 \\
Online DTP & 0.0 & 1.0 & 0.87 & 0.34 & 0.0 & 1.0 & 0.87 & 0.34 & 0.0 & 1.0 & 0.66 & 0.48 \\
Firm Age & 0.0 & 1.0 & 0.89 & 0.32 & 0.0 & 1.0 & 0.88 & 0.33 & 0.0 & 1.0 & 0.83 & 0.37 \\
Firm Size & 11 & 196 & 89.64 & 50.14 & 3 & 72 & 34.13 & 14.88 & 1.0 & 106 & 40 & 25.81 \\
BI & 3.70 & 5.91 & 4.81 & 0.59 & 3.14 & 5.72 & 4.55 & 0.63 & 3.77 & 6.23 & 5.03 & 0.59 \\
FL & 0.10 & 1.00 & 0.62 & 0.48 & 0.00 & 1.00 & 0.49 & 0.59 & 0.00 & 1.00 & 0.39 & 0.38 \\
AR & 0.00 & 1.21 & 0.13 & 0.22 & 0.01 & 1.50 & 0.19 & 0.34 & 0.00 & 2.12 & 0.32 & 0.48 \\
Paaccr & 0.71 & 1.10 & 0.87 & 0.11 & 0.86 & 1.47 & 1.14 & 0.15 & 0.84 & 1.38 & 1.07 & 0.12 \\
Tcaccr & 1.29 & 2.31 & 1.79 & 0.31 & 1.37 & 2.75 & 1.94 & 0.32 & 1.48 & 2.52 & 2.02 & 0.24 \\
AGGRE & 1.46 & 2.77 & 2.19 & 0.37 & 1.73 & 2.86 & 2.35 & 0.28 & 1.83 & 3.47 & 2.54 & 0.29 \\
\hline
\end{tabular}

Table 4. Correlation Coefficient Analysis

\begin{tabular}{|c|c|c|c|c|c|c|c|c|c|}
\hline & Variables & 1 & 2 & 3 & 4 & 5 & 6 & 7 & 8 \\
\hline 1. & DTP Start & 1 & & & & & & & \\
\hline 2. & DTP Expense & 0.015 & 1 & & & & & & \\
\hline 3. & $\begin{array}{l}\text { Specific Audit } \\
\text { Committee }\end{array}$ & 0.117 & $0.225^{* *}$ & 1 & & & & & \\
\hline 4. & Online DTP & -0.070 & 0.123 & $0.357^{* *}$ & 1 & & & & \\
\hline 5. & $A R$ & -0.202 & -0.088 & -0.080 & -0.038 & 1 & & & \\
\hline 6. & Paaccr & $0.216^{* *}$ & 0.091 & 0.069 & -0.019 & $-0.879^{* *}$ & 1 & & \\
\hline 7. & Tcaccr & $0.318^{* *}$ & 0.128 & 0.094 & -0.034 & $-0.680^{* *}$ & $0.780^{* *}$ & 1 & \\
\hline 8. & AGGRE & $0.290^{* *}$ & 0.120 & 0.083 & -0.046 & $-0.715^{* *}$ & $0.895^{* *}$ & $0.963^{* *}$ & 1 \\
\hline
\end{tabular}

Table 3 indicates that the number of firms that have specific audit committee training and development is lowest in Pakistan with a mean value of 0.66 ; in addition, the trend for online DTP is lowest in Pakistan with a mean value of 0.83 . The firm age is 196 years for the Australian sample, which is the highest of all three countries, and the maximum firm age in Malaysia is 72 years.

The correction coefficient analysis results of the variables are presented in Table 4 below. The results indicate that starting director training programs (DTP Start) early is positively correlated with financial re- porting quality. However, 'Specific AC' was not correlated to any of the financial reporting measures. In addition, the other DTP variables were not correlated to any of the financial reporting measures.

\section{Regression Results}

Tables 5 through 8 report the impact of DTP on the financial reporting quality of firms that operate in Australia, Malaysia and Pakistan.

Table 5 indicates that the dependent variable AR is positively associated with starting DTP early in Pakistan and Australia and DTP expenditures in Austra- 
Table 5. AR as the Dependent Variable

\begin{tabular}{lccc}
\hline & Australia & Malaysia & Pakistan \\
\hline DTP Start & $3.70^{* *}$ & -1.72 & $2.11^{* *}$ \\
DTP Expenses & $3.93^{* *}$ & -0.65 & -0.29 \\
Specific DTP for Audit & -0.54 & -0.23 & -0.49 \\
Committee & $2.34^{* *}$ & -0.28 & 0.78 \\
Online DTP & -1.13 & $-3.59^{* *}$ & -1.57 \\
Firm Age & $-7.08^{* *}$ & $-7.66^{* *}$ & $-6.63^{* *}$ \\
Firm Size & 5.02 & 6.56 & 5.98 \\
Financial Leverage & 0.56 & 0.55 & 0.75 \\
Board Independence & & & $38.7 \%$ \\
R $^{2}$ & $65.9 \%$ & $56.7 \%$ & $34.3 \%$ \\
Adj. R & $62.0 \%$ & $53.0 \%$ & 8.75 \\
F-Statistics & 17.03 & 15.34 & 0.000 \\
Prob. & 0.000 & 0.000 & \\
\hline
\end{tabular}

Table 6. PAaccr as the Dependent Variable

\begin{tabular}{lccc}
\hline & Australia & Malaysia & Pakistan \\
\hline DTP Start & 1.92 & 1.79 & -1.23 \\
DTP Expenses & $2.79^{* *}$ & 0.83 & 1.08 \\
Specific DTP for Audit & -1.78 & 0.27 & 1.68 \\
Committee & $3.27^{* *}$ & -0.24 & $1.97^{* *}$ \\
Online DTP & 1.167 & -2.44 & 0.53 \\
Firm Age & $-6.43^{* *}$ & $-8.25^{* *}$ & $-8.91^{* *}$ \\
Firm Size & 5.88 & 5.74 & 6.59 \\
Financial Leverage & 0.59 & 0.85 & 0.66 \\
Board Independence & & & $51.7 \%$ \\
R $^{2}$ & $61.5 \%$ & $57.1 \%$ & $48.2 \%$ \\
Adj. R & $57.2 \%$ & $53.4 \%$ & 14.78 \\
F-Statistics & 14.13 & 15.57 & 0.000 \\
Prob. & 0.000 & 0.000 & \\
\hline
\end{tabular}

lia are positively associated with AR. The results of the coefficient analysis indicate that the model used in this study is statistically significant at a level of $5 \%$ ( $\mathrm{p}<0.05)$.In this study, the $\mathrm{R}^{2}$ when AR was the dependent variable was $65.9 \%, 56.7 \%$ and $38.7 \%$, which was adjusted to better fit the model in the population and the final adjusted $\mathrm{R}^{2}$ was $62 \%, 53 \%$ and $34.3 \%$, respectively, for Australia, Malaysia and Pakistan.

In addition, the results indicate that firm size is significantly negatively correlated with the financial reporting measure "AR" in Australia, Malaysia and Pakistan. However, Firm age is negatively associated 
Table 7. TCaccr as the Dependent Variable

\begin{tabular}{lccc}
\hline & Australia & Malaysia & Pakistan \\
\hline DTP Start & 1.09 & $3.05^{* *}$ & -0.34 \\
DTP Expenses & 1.89 & 0.82 & 0.12 \\
Specific DTP for Audit & -1.02 & 0.48 & 1.71 \\
Committee & $3.46^{* *}$ & -0.38 & 0.21 \\
Online DTP & 0.99 & $-4.19^{* *}$ & -0.78 \\
Firm Age & $-3.24^{* *}$ & $-3.88^{* *}$ & $-6.83^{* *}$ \\
Firm Size & 4.59 & 5.15 & 5.25 \\
Financial Leverage & 0.84 & 0.67 & 0.88 \\
Board Independence & & & $40.6 \%$ \\
R $^{2}$ & $46.3 \%$ & $42.3 \%$ & $36.3 \%$ \\
Adj. R & $40.2 \%$ & $37.4 \%$ & 9.450 \\
F-Statistics & 7.624 & 8.597 & 0.000 \\
Prob. & 0.000 & 0.000 & \\
\hline
\end{tabular}

Table 8. AGGRE as the Dependent Variable

\begin{tabular}{lccc}
\hline & Australia & Malaysia & Pakistan \\
\hline DTP Start & 1.82 & $2.66^{* *}$ & -0.25 \\
DTP Expenses & $2.56^{* *}$ & 0.88 & 0.58 \\
Specific DTP for Audit & -1.35 & 0.42 & 1.96 \\
Committee & $3.47^{* *}$ & -0.49 & 1.45 \\
Online DTP & 0.89 & $-3.27^{* *}$ & -0.75 \\
Firm Age & $-5.20^{* *}$ & $-5.57^{* *}$ & $-7.58^{* *}$ \\
Firm Size & 5.26 & 5.88 & 5.65 \\
Financial Leverage & 0.78 & 1.06 & 0.89 \\
Board Independence & & & $45.6 \%$ \\
R $^{2}$ & $57.1 \%$ & $47.1 \%$ & $41.6 \%$ \\
Adj. R & $52.3 \%$ & $42.6 \%$ & 11.57 \\
F-Statistics & 11.76 & 10.42 & 0.000 \\
Prob. & 0.000 & 0.000 & \\
\hline
\end{tabular}

with financial reporting quality in Malaysia and the trend of using online DTP is positively associated with "AR" in Australia.

Table 6 indicates that the dependent variable PAaccr is positively associated with DTP expenditures and Online DTP in Australia. Online DTP is also posi- tively associated with the quality of financial reporting in Pakistan, and firm size (FSIZE) is negatively associated with the quality of financial reporting for all three countries. The results of the coefficient analysis indicate that the model is statistically significant at a level of $5 \%(\mathrm{p}<0.05)$. In this study, the $\mathrm{R}^{2}$ when 

Finally, academics who seek to broaden their experiences by serving on corporate boards may find the information useful in making decisions regarding their personal development.

The results of the analysis demonstrate that firm size and firm age negatively affect the quality of financial reporting. There are several possible reasons for this influence. Because of their market power, larger and older firms are able to charge higher prices and subsequently earn higher profits. In addition, higher profits could result from economies of scale and stronger negotiating power that provides larger firms with more favorable financing conditions. In addition to inflexible organization structures and technology, a change in the strategic logic that is used by firms (it became more important to survive during a global economic crisis than to increase profitability) may explain the weak relationships between firm size and firm age and reporting quality.

This study contributes to the extant literature in three dimensions: first, this study combines marketbased and standard accounting financial indicators as measures of financial reporting to test the predictions of agency theory. Second, this study provides new empirical evidence regarding the effects of director training programs on a firm's financial reporting quality in all sectors of the Asia Pacific stock markets. Finally, this study provides additional evidence regarding the effect of director training on financial reporting in developed and developing countries by using the same variables and analysis techniques.

\section{References:}

Agrawal, A., \& Chadha, S. (2005). Corporate governance and accounting scandals. The Journal of Law and Economics, 48(2), 371-406.

Aguinis, H., \& Kraiger, K. (2009). Benefits of training and development for individuals and teams, organizations and society. Annual Review of Psychology, 60, 451-474.

Armstrong, C. S., Barth, M. E., Jagolinzer, A. D., \& Riedl, E. J. (2010). Market reaction to the adoption of IFRS in Europe. The Accounting Review, 85(1), 31-61.

Arthurs, J. D., Hoskisson, R. E., Busentiz, L. W., \& Johnson, R. A. (2008). Managerial agents watching other agents: Multiple agency conflicts regard- ing underpricing in IPO firms. Academy of Management Journal, 51(2): 277-294.

Ashbaugh, H., LaFond, R., \& Mayhew, B. W. (2003). Do nonaudit services compromise auditor independence? Further evidence. The Accounting Review, 78(3), 611-693.

Baber, W., Liang, L., \& Zhu Z. (2012). Associations between internal and external corporate governance characteristics: Implications for investigating financial accounting restatements. Accounting Horizons, 26(2), 219-237.

Bamber, L. S., Jiang, J., \& Wang, I. Y. (2010). What's my style? The influence of top managers on voluntary corporate financial disclosure. The Accounting Review, 85(4), 1131-1162.

Barling, J. B., Weber, T., \& Kelloway, E. K. (1996). Effects of transformational leadership training on attitudinal and financial outcomes: A field experiment. Journal of Applied Psychology, 81(6), 827832.

Beekes, W., \& Brown, P. (2006). Do better-governed Australian firms make more informative disclosures. Journal of Business Finance \& Accounting, 33(3-4), 422-450.

Beekes, W., Pope, P., \& Young, S. (2004). The link between earnings and timeliness, earnings conservatism and board composition: Evidence from the UK. Corporate Governance: An International Review, 12(1), 47-59.

Bergstresser, D., \& Philippon, T. (2006). CEO Incentives and Earnings Management. Journal of Financial Economics, 80(3), 511-529.

Bertrand, M., \& Schoar, A. (2003). Managing with style: The effects of managers on firm policies. The Quarterly Journal of Economics, 118(4),1169-1208.

Biddle, G. C., Hilary, G., \& Verdi, R. S. (2009). How does financial reporting quality relate to investments efficiency? Journal of Accounting and Economics, 48(2-3), 112-131.

Bradbury, M., Mak, Y. T., \& Tan, S. M. (2006). Board characteristics, audit committee characteristics and abnormal accruals. Pacific Accounting Review, 18(2), 47-68.

Bowen, R. M., Call, A. C., \& Rajgopal, S. (2010). Whistle-blowing: Target firm characteristics and economic consequences. The Accounting Review, 85(4), 1239-1271. 
Brown, L., \& Caylor, M. (2006). Corporate governance and firm valuation. Journal of Accounting and Public Policy, 25(4), 409-434.

Burke, L. A., \& Hutchins, H. M. (2007). Training transfer: An integrative literature review. Human Resource Development Review, 6(3), 263-296.

Chen, X., Harford, J., \& Li, K. (2007). Monitoring: Which institutions matter? Journal of Financial Economics, 86(2), 279-305.

Chen, C. J. P., \& Jaggi, B. (2000). Association between independent non-executive directors, family control and financial disclosures in Hong Kong. Journal of Accounting and Public Policy, 19(4-5), 285-310.

Cheng, Q., \& Warfield, T. D. (2005). Equity incentives and earnings management. The Accounting Review, 80(2), 441-476.

Dechow, P. M., \& Dichev, I. D. (2002). The quality of Accruals and Earnings: The role of Accrual Estimation Errors. The Accounting Review, 77, 35-59.

Dechow, P., Ge, W., \& Schrand, C. (2010). Understanding earnings quality: A review of the proxies their determinants and their consequences. Journal of Accounting and Economics, 50(2-3), 344-401.

Decker, W. H., \& Calo, T. J. (2007). Observers' impressions of unethical persons and whistleblowers. Journal of Business Ethics, 76(3), 309-318.

Dimitropoulos, P. E., \& Asteriou, D. (2010). The effect of board composition on the informativeness and quality of annual earnings: Empirical evidence from Greece. Research in International Business and Finance, 24(2), 190-205.

Doh, J. P. (2003). Can leadership be taught? Perspectives from management educators. Academy of Management Learning \& Education, 2(1), 54-67.

Dvir, T., Eden, D., Avolio, B. J., \& Shamir, B. (2002). Impact of transformational leadership on follower development and performance: A field experiment. The Academy of Management Journal, 45(4), 735-744.

Dyreng, S. D., Hanlon, M., \& Maydew, E. L. (2010). The effects of managers on corporate tax avoidance. The Accounting Review, 85(4), 1163-1190.

Easley, D., \& O'Hara, M. (2004). Information and the cost of capital. The Journal of Finance, 59(4) 1553-1583.
Efendi, J., Srivastava, A., \& Swanson, E. P. (2007). Why do corporate managers misstate financial statements? The role of option compensation and other factors. Journal of Financial Economics, 85(3), 667-708.

Erickson, M., Hanlon, M., \& Maydew, E. L. (2006). Is there a link between executive equity incentives and accounting fraud? Journal of Accounting Research, 44(1), 113-143.

Finkelstein, S., \& D’Aveni, R. A. (1994). CEO duality as a double-edged sword: How boards of directors balance entrenchment avoidance and unity of command. The Academy of Management Journal, 37(5), 1079-1108.

Firth, M., Fung, P., \& Rui, O. (2007). Ownership, twotier board structure, and the informativeness of earnings: Evidence from China. Journal of Accounting and Public Policy, 26(4), 463-496.

Foss, N. J., Lando, H., \& Thomsen, S. (2000). The Theory of the firm. In B. Bouckaert \& G. De Geest (Eds.), Encyclopedia of Law and Economics, Volume III. The Regulation of Contracts (pp. 631658). Cheltenham, UK: Edward Elgar.

Francis, J., LaFond, R., Olsson, P., \& Schipper, K. (2005). The market pricing of accruals quality. Journal of Accounting and Economics, 39(2), 295-327.

Grossman, W., \& Haskisson, R. E. (1998). CEO pay at the crossroads of Wall Street and Main: Toward the strategic design of executive compensation. Academy of Management Executive, 12(1), 43-57.

Hambrick, D. C., \& Mason, P. A. (1984). Upper echelons: The organization as a reflection of its top managers. The Academy of Management Review, 9(2), 193-206.

Hambrick, D. C., \& Fukutomi, G. D. S. (1991). The seasons of a CEO's tenure. The Academy of Management Review, 16(4), 719-742.

Hassan, R. A., Fuwad, B. A., \& Rauf, A. I. (2010). Pretraining motivation and the effectiveness of transformational leadership training: An experiment. Academy of Strategic Management Journal, 9(2), 123-131.

Hermalin, B. E., \& Weisbach, M. S. (1998). Endogenously chosen boards of directors and their monitoring of the CEO. The American Economic Review, 88(1), 96-118. 
Hermalin, B. E., \& Weisbach, M. S. (2003). Boards of directors as an endogenously determined Institution: A survey of the economic Literature. Federal Reserve Bank of New York Economic Policy Review, 9(1), 7-26.

Howell, J. M., \& Frost, P. J. (1989). A laboratory study of charismatic leadership. Organizational Behavior and Human Decision Processes, 43(2), 243-269.

Hunt, J. W., \& Baruch, Y. (2003). Developing top managers: The impact of interpersonal skills training. Journal of Management Development, 22(8), 729-752.

Hutchinson, M., \& Gul, F. A. (2004). Investment opportunity set, corporate governance practices and firm performance. Journal of Corporate Finance, 10(4), 595-614.

Karamanou, I., \& Vafeas, N. (2005). The association between corporate boards, audit committees, and management earnings forecasts: An empirical analysis. Journal of Accounting Research, 43(3), 453- 486

Kim, D., \& Qi, Y. (2010). Accruals quality, stock returns, and macroeconomic conditions. The Accounting Review, 85(3), 937-978.

Kirkpatrick, S. A., \& Locke, E. A. (1996). Direct and indirect effects of three core charismatic leadership components on performance and attitudes. Journal of Applied Psychology, 81(1), 36-51.

Klein, A. (2002). Audit committee, board of director characteristics, and earnings management. Journal of Accounting and Economics, 33(3), 375-400

Kothari, S. P., Leone, A. J., \& Wasley, C. E. (2005). Performance matched discretionary accrual measures. Journal of Accounting and Economics, 39(1), 163-197.

La Porta, R., Lopez-de-Silanes, F., Shleifer, A., \& Vishny, R. W. (1998). Law and finance. The Journal of Political Economy, 106(6), 1113-1155.

Larcker, D. F., Richardson, S. A., \& Tuna, I. (2007). Corporate governance, accounting outcomes and organizational performance. The Accounting Review, 82(4), 963-1008.

Matta, E., \& Beamish, P. W. (2008). The accentuated CEO career horizon problem: Evidence from international acquisitions. Strategic Management Journal, 29(7), 683-700.
McNichols, M. F. (2002). Discussion of the quality of accruals and earnings: The role of accrual estimation errors. The Accounting Review, 77, 61-69.

McNichols, M. F., \& Stubben, S. R. (2008). Does earnings management affect firms' investment decisions? The Accounting Review, 83(6), 1571-1603.

Mole, G. (2000). Managing management development. Buckingham, UK: Open University Press.

Owolabi, S. A., Obiakor, R. T., \& Okwu, A. T. (2011). Investigating Liquidity - Profitability Relationship in Business Organization: A Study of Selected Quoted Companies in Nigeria. British Journal of Economics, Finance and Management Sciences, 1(2), 17-25.

Parry, K. W., \& Sinha, P. N. (2005). Researching the trainability of transformational organizational leadership. Human Resource Development International, 8(2), 165-183.

Peasnell, K. V., Pope, P. F., \& Young, S. (2005). Board monitoring and earnings management: Do outside directors' influence abnormal accruals? Journal of Business Finance and Accounting, 32(7-8), 1311-1346.

Petra, S. T. (2007). The effects of corporate governance on the informativeness of earnings. Economics of Governance, 8(2), 129-152.

Prowse, S. D. (1992). The structure of corporate ownership in Japan. Journal of Finance, 47(3), 1121-1140.

Raheman, A., \& Nasr, M. (2007). Working capital management and profitability: Case of Pakistani firms. International Review of Business Research Papers, 3(1), 279- 300.

Sánchez-Ballesta, J. P., \& García-Meca, E. (2007). A meta-analytic vision of the effect of ownership structure on firm performance. Corporate Governance: An International Review, 15(5), 879-893.

Sloan, R. G. (2001). Financial accounting and corporate governance: A discussion. Journal of Accounting and Economics, 32(1-3), 335-347.

Srinidhi, B. N., \& Gul, F. A. (2007). The differential effects of auditors' nonaudit and audit fees on accrual quality. Contemporary Accounting Research, 24(2), 595-629.

Tucker, J. W., \& Zarowin, P. A. (2006). Does income smoothing improve earnings informativeness? The Accounting Review, 81(1), 251-270. 
Vijayakumar, A., \& Tamizhselvan, P. (2010). Corporate size and profitability: An empirical analysis. Journal for Bloomers of Research, 3(1), 44-53.

Wiersema, M. F., \& Bantel, K.A. (1992). Top management team demography and corporate strategic change. The Academy of Management Journal, 35(1), 91-121.

Yasser, Q. R., \& Mamun, A.A. (2015). The impact of CEO duality attributes on earnings management in the East. Corporate Governance, 15(5), 706-718.

Yeo, G. H. H., Tan, P. M. S., Ho, K. W., \& Chen, S. (2002). Corporate ownership structure and the informativeness of earnings. Journal of Business Finance and Accounting, 29(7-8), 1023-1046. 
